\title{
Regulation of bacterial motility in response to low pH in Escherichia coli: the role of H-NS protein
}

\author{
Olga A. Soutourina, ${ }^{1} \dagger$ Evelyne Krin, ${ }^{1}$ Christine Laurent-Winter, ${ }^{2}$ \\ Florence Hommais, ${ }^{1}$ Antoine Danchin ${ }^{1}$ and Philippe N. Bertin ${ }^{1} \ddagger$
}

Author for correspondence: Philippe N. Bertin. Tel: +32 143334 36. Fax: + 3214320313.
e-mail: pbertin@sckcen.be

Unité de Génétique des Génomes Bactériens ${ }^{1}$ and

The effect of detrimental conditions on bacterial motility in Escherichia coli was investigated. Expression profiling of mutant $E$. coli strains by DNA arrays Génopole-Plateau Protéomique2, Institut Pasteur, Paris, France and analysis of phenotypic traits demonstrated that motility and low-pH resistance are coordinately regulated. Analysis of transcriptional fusions suggests that bacterial motility in response to an acidic environment is mediated via the control by H-NS of flhDC expression. Moreover, the results suggested that the presence of an extended mRNA 5' end and DNA topology are required in this process. Finally, the presence of a similar regulatory region in several Gram-negative bacteria implies that this mechanism is largely conserved.

Keywords: acidic pH, osmolarity, DNA supercoiling, DNA array

\section{INTRODUCTION}

Complex cellular responses are often controlled by regulatory networks in which transcription factors regulate the expression of a diverse set of target genes. In eukaryotes such complex systems are implicated in cell differentiation into specialized tissues and in the maintenance of tissue homeostasis (Arnold \& Winter, 1998; Kawakami et al., 2000; Relaix \& Buckingham, 1999). In prokaryotes, multiple regulatory networks are usually organized in a similar way to those in higher organisms, with master regulatory genes at the top of the hierarchy, ensuring adequate responses and/or transformation into another stable cellular state to fine tune cellular metabolism. As an example, RpoS is a central element that governs the expression of bacterial stress- or stationary-phase-induced genes (HenggeAronis, 1999). Studies of genetic circuits such as those involved in bacteriophage infection, chemotaxis or the cell division cycle in prokaryotes have also provided important insight into the understanding of regulatory networks (Huang, 1999).

\footnotetext{
†Present address: Laboratoire de Biochimie, UMR 7654, CNRS-Ecole Polytechnique, 91128 Palaiseau Cedex, France.

$\ddagger$ Present address: Laboratory of Microbiology, Boeretang 200, B-2400 Mol, Belgium.

Abbreviation: CAT, chloramphenicol acetyltransferase.
}

Bacterial flagellum biosynthesis is under the control of the $f l h D C$ master operon, which governs motility and chemotaxis, as well as differentiation into swarming cells in enterobacteria. Moreover, this operon ensures global communication between flagellar genes and external factors, as well as cell division (Aizawa \& Kubori, 1998). The complex motility and chemotaxis system in Escherichia coli includes nearly 50 genes organized in an ordered cascade in which the expression of a gene located at a given level requires the transcription of another one at a higher level (Macnab, 1996). This system is subject to a complex regulation by multiple environmental factors and regulatory proteins. For example, flagellum biosynthesis is sensitive to catabolite repression (Adler \& Templeton, 1967; Silverman \& Simon, 1974; Yokota \& Gots, 1970) and is inhibited by stressful environmental conditions, such as increased temperature and high osmolarity (Adler \& Templeton, 1967; Li et al., 1993). Moreover, numerous mutations in stress-related genes, such as those encoding heat-shock proteins, membrane components or DNA replication initiation factors, are known to affect motility (Farr et al., 1989; Kitamura et al., 1994; Mizushima et al., 1995, 1997; Shi et al., 1992, 1993a) by repressing transcription of the flhDC master operon (Mizushima et al., 1995, 1997; Shi et al., 1993b). Unlike flhDC transcriptional control by cAMP-CAP complex (Soutourina et al., 1999), the mechanism by which stressrelated conditions affect master operon expression remains still largely unknown. 
H-NS is a nucleoid-associated protein known to be involved in the control of motility in E. coli (Bertin et al., 1994) and in Salmonella typhimurium (Hinton et al., 1992). This protein positively controls the master flagellar operon but the mechanism of this regulation remains unclear (Kutsukake, 1997; Soutourina et al., 1999). In the present study we demonstrated that flagellar gene expression is inhibited under low-pH conditions and that this regulation of the $f l h D C$ master operon may be dependent on the H-NS protein. For the first time, we provide evidence that the $5^{\prime}$ end of mRNA plays a crucial role in $f l h D C$ expression in response to environmental factors.

\section{METHODS}

Bacterial strains and growth conditions. Bacterial strains and plasmids used in this study are listed in Table 1 . Strains were grown in Luria-Bertani (LB), tryptone, M9 or M63 media (all media as in Miller, 1992), supplemented as indicated with $0.1 \%(\mathrm{w} / \mathrm{v})$ Casamino acids, $0.4 \%(\mathrm{w} / \mathrm{v})$ sodium succinate, $0.4 \%(\mathrm{w} / \mathrm{v})$ glycerol or $0.4 \%(\mathrm{w} / \mathrm{v})$ glucose as a carbon source. Tryptone swarm plates containing 1\% Bacto-tryptone, $0.5 \% \mathrm{NaCl}$ and $0.3 \%$ Bacto-agar were used to test bacterial motility as previously described (Bertin et al., 1999), except for plates at $\mathrm{pH} 4 \cdot 6$, which contained $0.5 \%$ Bacto-agar. Metabolism of $\beta$-glucosides was tested on MacConkey indicator agar plates with $1 \%$ salicin as a carbon source. When required, antibiotics were added at the following concentration: ampicillin, $50 \mu \mathrm{g} \mathrm{ml}^{-1}$, and kanamycin, $20 \mu \mathrm{g} \mathrm{ml}^{-1}$. All experiments were performed in accordance with the European regulation requirements concerning the contained use of Genetically Modified Organisms of Group I (agreement no. 2735).

Chloramphenicol acetyltransferase (CAT) assay. Strains were grown in tryptone medium supplemented with sodium succinate or M9 medium supplemented with Casamino acids and glycerol at $\mathrm{pH} 7 \cdot 0$ or $4 \cdot 6$ to an $\mathrm{OD}_{600}$ of $0 \cdot 15$ to $0 \cdot 3$. CAT activity was measured with 5,5'-dithiobis-2-nitrobenzoic acid (DTNB) on cell extracts as previously described (Soutourina et al., 1999).

Resistance to low $\mathrm{pH}$. Strains were grown to stationary phase overnight in M9 medium, $\mathrm{pH} 5 \cdot 5$, supplemented with glucose and Casamino acids. Acidic stress was analysed in M9 medium at $\mathrm{pH} 2.5$ supplemented with $0.012 \%$ glutamate as previously described (Hommais et al., 2001).

Two-dimensional gel electrophoresis. Strains were grown in M9 medium supplemented with Casamino acids and glycerol at $\mathrm{pH} 7 \cdot 0$ or $4 \cdot 6$ to an $\mathrm{OD}_{600}$ of $0 \cdot 7$. Total protein extracts and two-dimensional gel electrophoresis were carried out as previously described (Hommais et al., 2001; Laurent-Winter et al., 1997).

Expression profiling. Bacterial cells were grown in M63 minimal medium supplemented with glucose (Miller, 1992) to an $\mathrm{OD}_{600}$ of $0 \cdot 6$. Handling of RNA, cDNA synthesis from $10 \mu \mathrm{g}$ RNA, hybridization on DNA arrays (Panorama E. coli gene arrays from Sigma-GenoSys Biotechnologies) and data analysis were performed as previously described (Hommais et al., 2001). Briefly, hybridization probes were generated from $10 \mu \mathrm{g}$ RNA following standard cDNA synthesis using $\left[\alpha^{-33} \mathrm{P}\right] \mathrm{dCTP}\left(7 \cdot 4 \times 10^{13}-1 \cdot 1 \times 10^{14} \mathrm{~Bq} \mathrm{mmol}^{-1}\right.$, New England Nuclear), AMV reverse transcriptase (Roche) and E. coli labelling primers (Sigma-Genosys). The prehybridization and hybridization were carried out according to the manufacturer's recommendations with some modifications (Hommais et al., 2001). Blots were exposed to PhosphorImager screen (Molecular Dynamics) and were then scanned on a $445 \mathrm{SI}$ PhosphorImager. The intensity of each dot was measured with the XDOTSREADER software (Cose) and analysed using an Excel spreadsheet.

In vitro transcription assays. In vitro transcription experiments were performed with pDIA546 containing the entire flhDC regulatory region as previously described (Soutourina et al., 1999). Plasmid pDIA546 was restricted by EcoRI for $2 \mathrm{~h}$ at $37^{\circ} \mathrm{C}$ and used as linearized template for in vitro transcription.

Table 1. Bacterial strains and plasmids

\begin{tabular}{|c|c|c|}
\hline $\begin{array}{l}\text { Strain or } \\
\text { plasmid }\end{array}$ & Relevant genotype & Reference or source \\
\hline \multicolumn{3}{|l|}{ Strain } \\
\hline MG1655 & Wild-type & CGSC 6300 \\
\hline PS2209 & Wild-type & Bertin et al. (1994) \\
\hline PS2652 & PS2209 hns-1001 & Bertin et al. (1994) \\
\hline FB8 & Wild-type & Bruni et al. (1977) \\
\hline BE1410 & FB8 hns-1001 & Laurent-Winter et al. (1997) \\
\hline BE2120 & hns-1001 carrying a $m^{+} t^{+}$suppressor mutation & This study \\
\hline BE2121 & hns-1001 carrying a $m o t^{+}$suppressor mutation & This study \\
\hline \multicolumn{3}{|l|}{ Plasmid } \\
\hline pDIA528 & pKK232-8-derivative carrying the $f l h D C$ promoter $(\mathrm{nt}-213$ to +78$)$ & Soutourina et al. (1999) \\
\hline pDIA545 & pKK232-8 derivative carrying the $f l h D C$ regulatory region $(\mathrm{nt}-213$ to +205$)$ & Soutourina et al. (1999) \\
\hline pDIA546 & pJCD01 derivative carrying the $f l h D C$ regulatory region $(\mathrm{nt}-213$ to +202$)$ & Soutourina et al. (1999) \\
\hline pDIA559 & pKK232-8-derivative carrying the $f l i C$ promoter region & Soutourina et al. (1999) \\
\hline pPM61 & $\begin{array}{l}\text { ColE1 derivative multicopy expression vector carrying the } f l h D C \text { operon under its } \\
\text { native promoter }\end{array}$ & Bartlett et al. (1988) \\
\hline
\end{tabular}




\section{RESULTS}

\section{Isolation and characterization of suppressor mutations}

The comparative analysis of expression profiles in $E$. coli wild-type and hns strains (Hommais et al., 2001) revealed two major alterations in the hns background: on the one hand, a decrease in flagellar gene expression, and on the other hand, an increase in the acidic $\mathrm{pH}$ resistance gene expression, suggesting that these two $\mathrm{H}$ -
NS-controlled phenotypes may be related to each other. To test this possible link, we isolated and characterized in an hns background suppressor mutations with regard to motility. Several spontaneous mutants showing $\mathrm{H}$ NS-independent swarming were isolated at a frequency of about $10^{-9}$ by incubating hns strains on semi-solid agar plates at $30^{\circ} \mathrm{C}$ for $24-48 \mathrm{~h}$, and two of them were purified. Attempts to locate these suppressor mutations by genetic techniques were unsuccessful, which suggests that they may involve more than one gene, e.g. an

Table 2. Effect of suppressor mutations on various H-NS-related phenotypes

\begin{tabular}{|lcccc|}
\hline Strain (phenotype) & Mucoidy & $\begin{array}{c}\boldsymbol{\beta} \text {-Glucoside } \\
\text { utilization } \dagger\end{array}$ & Motility & Survival $(\%) \mathbb{S}$ \\
\hline FB8 (wild-type) & - & - & $30+3$ & $<0 \cdot 001$ \\
BE1410 $($ hns) & + & + & $3+1$ & $24+4$ \\
BE2120 $\left(m o t^{+}\right)$ & + & + & $18+2$ & $<0 \cdot 005$ \\
BE2121 $\left(m o t^{+}\right)$ & + & + & $21+2$ & $<0 \cdot 001$ \\
\hline
\end{tabular}

$*+$, Mucoid phenotype observed on LB medium; - , no mucoid phenotype.

$\dagger+$, Ability to metabolize $\beta$-glucoside revealed by the appearance of red colonies on MacConkeysalicin agar plates; - , lack of ability to metabolize $\beta$-glucoside, indicated by white colonies.

$\ddagger$ Diameter of the swarming ring (in $\mathrm{mm}$ ) after $15 \mathrm{~h}$ at $30^{\circ} \mathrm{C}$. Data are the mean values \pm standard deviations of three independent experiments.

\$Percentage survival is calculated as $100 \times$ number of c.f.u. per $\mathrm{ml}$ remaining after low-pH treatment divided by the initial c.f.u. per $\mathrm{ml}$ at time zero. Data are the mean values of three independent experiments.

Table 3. Expression profiling by DNA arrays of various $E$. coli strains

\begin{tabular}{|c|c|c|c|c|c|}
\hline \multirow[t]{2}{*}{ Gene } & \multicolumn{4}{|c|}{ Expression level* in strain (phenotype): } & \multirow[t]{2}{*}{ Function } \\
\hline & $\begin{array}{c}\text { FB8 } \\
\text { (wild-type) }\end{array}$ & $\begin{array}{c}\text { BE1410 } \\
(\text { hns })\end{array}$ & $\begin{array}{c}\mathrm{BE} 2120 \\
\left(\boldsymbol{m o t}^{+}\right)\end{array}$ & $\begin{array}{c}\mathrm{BE} 2121 \\
\left(\boldsymbol{m o t}^{+}\right)\end{array}$ & \\
\hline & & & & & Flagellum biosynthesis \\
\hline$f \lg B$ & $0 \cdot 80$ & - & $0 \cdot 38$ & $1 \cdot 36$ & Proximal rod protein \\
\hline$f \lg D$ & $0 \cdot 67$ & - & $0 \cdot 61$ & $0 \cdot 86$ & Basal body rod modification protein \\
\hline$f \lg G$ & $0 \cdot 75$ & $0 \cdot 29$ & $0 \cdot 61$ & $1 \cdot 32$ & Distal rod protein \\
\hline $\operatorname{flg} K$ & $1 \cdot 02$ & - & $0 \cdot 80$ & $1 \cdot 04$ & Hook-associated protein 1 \\
\hline$f \lg L$ & $1 \cdot 02$ & - & $0 \cdot 44$ & $1 \cdot 34$ & Hook-associated protein 3 \\
\hline fliA & $0 \cdot 72$ & - & $0 \cdot 30$ & $0 \cdot 75$ & Flagella-specific sigma factor \\
\hline $\mathrm{fliC}$ & $7 \cdot 04$ & - & $0 \cdot 26$ & $0 \cdot 41$ & Flagellin \\
\hline$f l i D$ & $1 \cdot 57$ & - & $0 \cdot 44$ & $1 \cdot 66$ & Hook-associated protein 2 \\
\hline fliJ & $1 \cdot 10$ & $0 \cdot 12$ & $1 \cdot 01$ & $0 \cdot 95$ & Export for some substrates \\
\hline$f l i K$ & $0 \cdot 83$ & - & $0 \cdot 66$ & $1 \cdot 39$ & Hook length control protein \\
\hline & & & & & Acid $\mathrm{pH}$ resistance \\
\hline $\operatorname{gad} A$ & $0 \cdot 57$ & 16.98 & $2 \cdot 76$ & $2 \cdot 03$ & Glutamate decarboxylase $\alpha$ \\
\hline $\operatorname{gadB}$ & $0 \cdot 43$ & $15 \cdot 16$ & $2 \cdot 33$ & $1 \cdot 83$ & Glutamate decarboxylase $\beta$ \\
\hline $\operatorname{gadC}$ & $0 \cdot 26$ & $8 \cdot 91$ & $1 \cdot 21$ & $0 \cdot 39$ & Putative amino acid antiporter \\
\hline $\operatorname{gadX}$ & - & $3 \cdot 48$ & $2 \cdot 83$ & $0 \cdot 83$ & Regulatory protein \\
\hline hdeA & $0 \cdot 36$ & $10 \cdot 67$ & $2 \cdot 75$ & $0 \cdot 66$ & Putative chaperone-like protein involved in low $\mathrm{pH}$ resistance \\
\hline$h d e B$ & - & $9 \cdot 42$ & $2 \cdot 08$ & $0 \cdot 37$ & Involved in low $\mathrm{pH}$ resistance \\
\hline bdeD & - & $3 \cdot 17$ & $0 \cdot 40$ & $0 \cdot 57$ & Unknown function \\
\hline
\end{tabular}

*Expression level (arbitrary units) was measured as previously described (Hommais et al., 2001). -, Below the background level. 
essential locus with an additional compensatory mutation. The impossibility of transferring these mutations to other strains by P1 transduction or of obtaining strains with similar phenotype by transposon insertion further supports the possible existence of distant mutations. The presence of such multiple genetic alterations could be explained by the high frequency of spontaneous mutation observed in hns strains (Lejeune \& Danchin, 1990). A similar failure to characterize suppressor mutations involved in the thermoregulation of motility has been reported in Yersinia enterocolitica (Rohde et al., 1994).

To investigate the effect of the suppressor mutations on the physiology of E. coli, we tested various H-NSrelated phenotypes in strains BE2120 and BE2121. Like the original hns mutant, both strains remained mucoid and able to use salicin as a carbon source (Table 2). In contrast, the mutations reversed, as expected, the loss of motility on semi-solid medium. Surprisingly, the suppressor mutants also showed a strong susceptibility to low $\mathrm{pH}$, similar to that of the wild-type strain (Table 2).

To address the mechanism underlying the possible link between loss of motility and low $\mathrm{pH}$ resistance, expression profiling was performed using DNA arrays. As seen in Table 3, the major differences concerned the expression of genes involved in flagellum biosynthesis and in low $\mathrm{pH}$ resistance. Indeed, the transcript level of many flagellar genes measured in suppressor strains BE2120 and BE2121 was close to that in the wild-type strain. More importantly, a strong reduction in the expression of the gad and hde genes involved in resistance to low $\mathrm{pH}$ (Hommais et al., 2001) was observed in these mutants in comparison with the hns strain (Table 3). These results are consistent with the alteration of motility and acid resistance we observed (Table 2) and support a coordinate regulation by H-NS of both processes in E. coli.

The analysis of expression profiles of the suppressor mutants did not allow us to identify an altered expression of genes known to be involved in the control of motility, i.e. CsrA- or HdfR-encoding genes (Ko \& Park, 2000; Romeo, 1998; Wei et al., 2001). Furthermore, both genes were not mutated in the suppressor strains (data not shown). Finally, spontaneous mutants were also obtained in an hns stpA double mutant context (data not shown), suggesting that the motility reversion process we observed is independent of the presence of StpA, in agreement with our recent data (Bertin et al., 2001). Taken together, these observations suggest that these proteins do not play any role in the $\mathrm{H}$ NS-regulated control of motility and low $\mathrm{pH}$ resistance.

\section{Regulation of motility under acidic $\mathrm{pH}$ conditions}

In E. coli, the optimum $\mathrm{pH}$ for motility and chemotaxis is close to that for growth (Adler, 1973; Adler \& Templeton, 1967). However, the control of bacterial motility by acidic $\mathrm{pH}$, which can reflect the growth conditions frequently encountered by enterobacteria

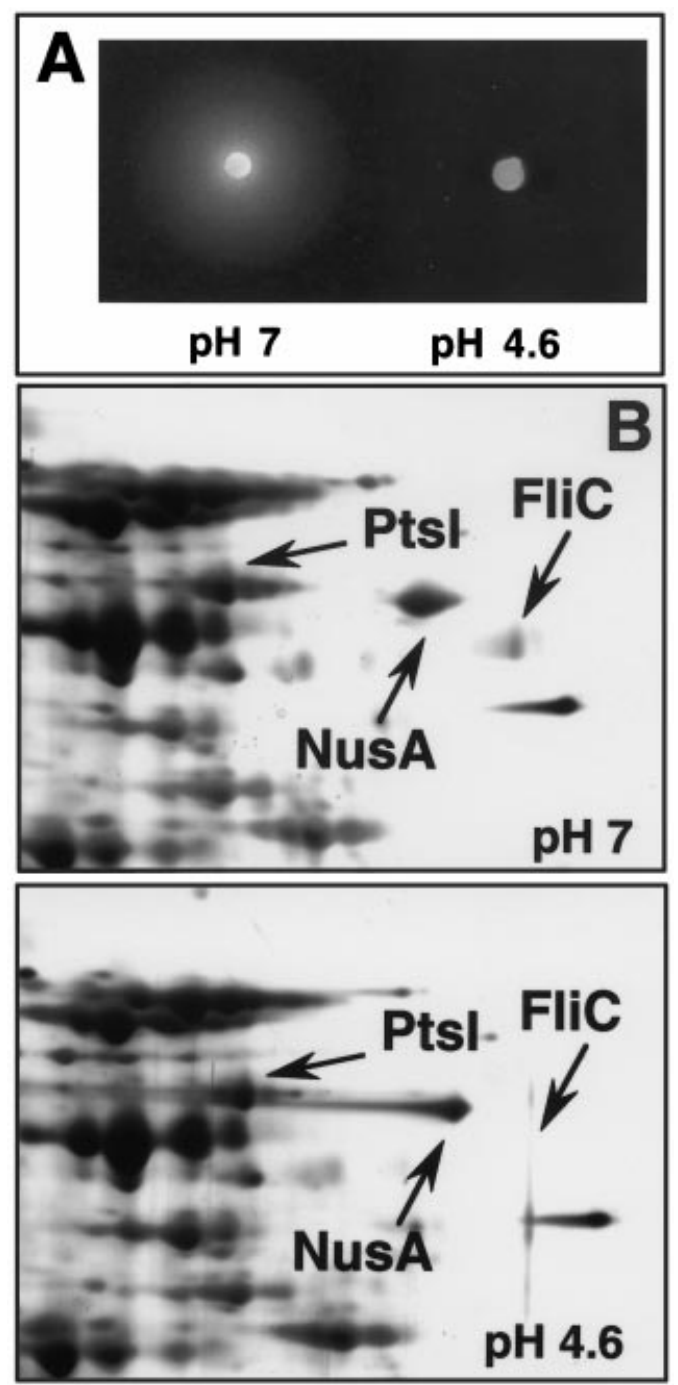

Fig. 1. Effect of acidic $\mathrm{pH}$ on motility and flagellin synthesis. (A) Motility of the $E$. coli wild-type strain was assayed on semi-solid medium plates at $\mathrm{pH} 7.0$ and at $\mathrm{pH} 4.6$. Plates were incubated for $13-15 \mathrm{~h}$ at $30^{\circ} \mathrm{C}$. (B) Protein extracts of wild-type strain MG1655 grown at $\mathrm{pH} \mathrm{7.0}$ and at $\mathrm{pH} 4.6$ were resolved by twodimensional electrophoresis and silver stained. Only the region in the vicinity of FliC is shown. FliC is indicated by an arrow. To facilitate the comparison, NusA and Ptsl are indicated as landmarks.

inside their host (Mahan et al., 1996), has not yet been well documented. To investigate the direct effect of low $\mathrm{pH}$ on motility, we tested the swarming behaviour of wild-type E. coli on semi-solid plates at neutral and acidic pH. As seen in Fig. 1(A), a loss of motility was observed under low $\mathrm{pH}$ conditions. To determine whether this alteration in swarming behaviour resulted from a lack of flagella, we analysed the flagellin content by two-dimensional gel electrophoresis. As seen in Fig. $1(\mathrm{~B})$, the spot corresponding to the FliC protein on our E. coli two-dimensional protein map (Hommais et al., 2001) was undetectable in the protein extract of bacteria grown at low $\mathrm{pH}$ by comparison with those grown at 


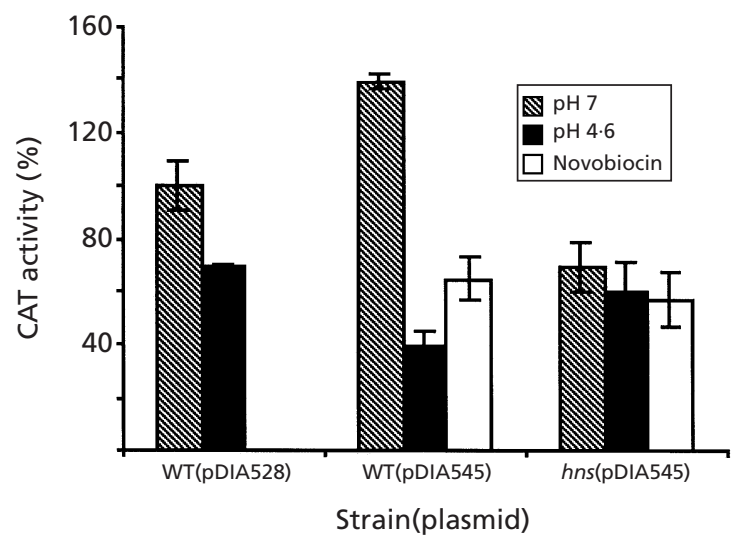

Fig. 2. Effect of low $\mathrm{pH}$ and novobiocin on flhDC transcription. The flhDC-cat transcriptional fusion activity was measured in exponential growth phase in M9 medium supplemented with $0.1 \%(\mathrm{w} / \mathrm{v})$ Casamino acids and $0.4 \%(\mathrm{w} / \mathrm{v})$ glycerol at $\mathrm{pH} 7$ and $\mathrm{pH} 4.6$ or in the presence of $200 \mu \mathrm{M}$ novobiocin. The data are the mean values from three independent assays. WT, wildtype; pDIA528, plasmid carrying the flhDC promoter; pDIA545, plasmid carrying the entire $f / h D C$ regulatory region.

neutral $\mathrm{pH}$. It has been proposed that disintegration of flagella into subunits occurs at acidic pH (Stocker \& Campbell, 1959; Weibull, 1948). However, to prevent unnecessary energy consumption - the cost to cell of flagellar synthesis is about $2 \%$ of total biosynthetic energy expenditure (Macnab, 1996) - it can be assumed that detrimental conditions such as acidic $\mathrm{pH}$ repress expression of flagellar genes. To test this hypothesis, we measured the expression level of the flagellin-encoding gene using a fliC-cat transcriptional fusion under neutral and acidic $\mathrm{pH}$ conditions. A sevenfold decrease in $f l i C$ transcription was observed at acidic as compared to neutral $\mathrm{pH}$ : CAT activities of $530 \pm 30$ and $68 \pm 8$ units were measured at $\mathrm{pH} 7 \cdot 0$ and $\mathrm{pH} 4 \cdot 6$, respectively (1 unit corresponds to $1 \mu \mathrm{mol}$ chloramphenicol acetylated per min per $\mu$ g protein).

\section{Regulation of the fIhDC expression by low $\mathrm{pH}$}

The $f h D C$ master operon, located at the top of the flagellum biosynthesis cascade, constitutes the major target for regulatory proteins, such as H-NS and cAMPCAP (Soutourina et al., 1999). To determine whether the control by acidic $\mathrm{pH}$ affected bacterial motility by downregulating the expression of the master operon, the motility of an E. coli wild-type strain overexpressing the flhDC operon (Table 1) was assayed under low-pH conditions. FlhDC overproduction from plasmid pPM61 resulted in a partial restoration of the motility defect (data not shown), suggesting that low $\mathrm{pH}$ affects the motility via the master regulator, as observed with some other environmental factors (Shi et al., 1993b). This hypothesis was tested with CAT transcriptional fusions carrying either the $f l h D C$ promoter region alone or the extended regulatory region that includes the mRNA untranslated $5^{\prime}$ end (Fig. 2). Our previous studies (Soutourina et al., 1999) have demonstrated a crucial role for the $f l h D C 5^{\prime}$ end in the positive control of the flagellar master operon by H-NS. In the wild-type strain, similar values were obtained under neutral and low-pH conditions from the transcriptional fusion carrying the promoter region alone on plasmid pDIA528. In contrast, a more than threefold decrease in CAT activity was measured under acidic $\mathrm{pH}$ in comparison with neutral $\mathrm{pH}$ from the transcriptional fusion carrying the entire flhDC regulatory region on plasmid pDIA545. A similar reduction in $f l h D C$ expression has been previously measured in E. coli strains subjected to various stresses, such as high osmolarity or increased temperature (Shi et al., 1993b), supporting a role for the flhDC $5^{\prime}$ end in the control of flagellar genes in response to acidic $\mathrm{pH}$.

Both low $\mathrm{pH}$ and hns mutation resulted in an up to threefold decrease in $f l h D C-$ cat activity in the presence of the $5^{\prime}$ end region. Such a reduction in $f l h D C$ expression has been previously observed in hns strains carrying a chromosomal flhDC-lac $Z$ transcriptional fusion (Soutourina et al., 1999). Moreover, a comparative analysis of the plasmid content revealed no difference between wild-type and hns strains (data not shown). This suggests that the reduced level of cat activity measured in the hns strain did not result from any effect of the mutation on the plasmid copy number of pKK232-8 derivatives, in accordance with the results obtained with plasmid pGR71 carrying the same origin of replication (Bertin et al., 1992). More importantly, no further reduction in transcription was observed in the hns mutant under low $\mathrm{pH}$ (Fig. 2), indicating that the effects of low $\mathrm{pH}$ and H-NS deficiency are not additive. This suggests that the control of bacterial motility in response to acidic $\mathrm{pH}$ is mediated by the H-NS protein. These results are in accordance with the coordinate regulation of motility and low $\mathrm{pH}$ response by $\mathrm{H}-\mathrm{NS}$ protein observed in suppressor mutants (Tables 2 and $3)$.

One possibility that could explain the role of H-NS in the control of gene expression is its implication in DNA topology (Higgins et al., 1988; Dorman et al., 2001). Moreover, some environmental factors or drugs that are known to inhibit bacterial motility also affect DNA supercoiling, e.g. high salt concentration or novobiocin (Anderson \& Bauer, 1978; Goldstein \& Drlica, 1984; Higgins et al., 1988; Shi et al., 1993b). The overexpression of DNA gyrase subunit GyrB resulted in a partial restoration of motility in an hns mutant (data not shown). Furthermore, in the presence of novobiocin, a DNA gyrase inhibitor decreasing DNA supercoiling, we observed a more than twofold decrease in $f l h D C$ activity from the flhDC transcriptional fusion containing the entire regulatory region, similar to that obtained in the presence of an bns mutation or at low $\mathrm{pH}$ (Fig. 2). Finally, as compared to the wild-type strain, which was non-motile in the presence of novobiocin $(28$ and $4 \mathrm{~mm}$ swarming ring diameter in the absence and presence of $200 \mu \mathrm{M}$ novobiocin, respectively), a significant restoration of motility was observed in the presence of plasmid pPM61 overexpressing the flhDC operon (10 $\mathrm{mm}$ swarming ring diameter). 


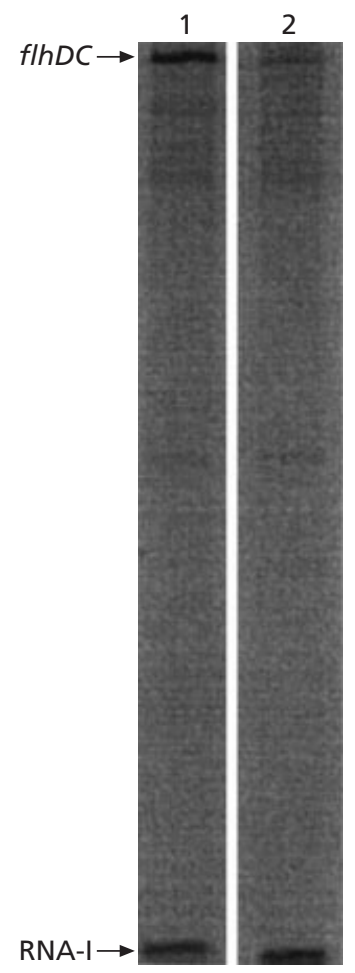

Fig. 3. Effect of plasmid DNA supercoiling on in vitro flhDC transcription assays. Supercoiled (1) and linearized plasmid pDIA546 (2) were incubated with RNA polymerase. Samples were subjected to electrophoresis on $7 \%$ polyacrylamide sequencing gel. The fIhDC transcript originating from the fIhDC promoter $(271 \mathrm{nt})$ and that from the RNA-I promoter located on the same plasmid (108 nt) used as a control are indicated by arrows.

To further investigate the effect of DNA topology on flhDC expression, we performed in vitro transcription experiments with either supercoiled or linearized plasmid pDIA546 carrying the entire $f l h D C$ regulatory region. A severe reduction in the flhDC transcription level was observed when linearized plasmid was used as a template (Fig. 3). This suggests that variations in DNA topology involving the $5^{\prime}$ end of the flhDC operon may play an important role in the transcriptional control of the flagellar master operon by H-NS in response to low $\mathrm{pH}$.

\section{DISCUSSION}

To date, only limited data are available on the motility control by acidic $\mathrm{pH}$ (Adler, 1973; Adler \& Templeton, 1967; Bowra \& Dilworth, 1981). The fact that bacterial flagella, with other extracellular organelles, are directly exposed to damage caused by acidic $\mathrm{pH}$ (Stocker \& Campbell, 1959; Weibull, 1948) suggests that these structures might be disintegrated under these conditions. Nevertheless, our results provide evidence that acidic $\mathrm{pH}$ regulates flagellar gene expression in E. coli by a transcriptional control on the flhDC master operon
(Figs 1 and 2). These results are consistent with general energy consumption considerations under detrimental conditions, flagellum biosynthesis being extremely expensive for the cell (Macnab, 1996), and also with the necessity to close the proton entrance during flagellum motor functioning by reducing the biosynthesis of this structure. Moreover, we demonstrated here a remarkable parallelism in the regulation of motility by the $\mathrm{H}$ NS protein and low pH (Tables 2 and 3, Fig. 2). In particular, we showed that the H-NS protein might play a central role in the $\mathrm{pH}$-mediated control of bacterial flagellum biosynthesis (Fig. 2). The control of flagellar master operon expression in response to low $\mathrm{pH}$ (Fig. 2) or high osmolarity (O.S., unpublished) requires an extended $f l h D C$ mRNA $5^{\prime}$ untranslated region. The comparative analysis of the upstream sequence of $f l h D C$ homologous operons in enterobacteria revealed the presence of a similar domain in many Gram-negative bacteria. Furthermore, a long $5^{\prime}$ untranslated region has also been identified in the master flagellar regulatory gene of polarly flagellated bacteria of the genera Vibrio and Pseudomonas (Soutourina et al., 2001). Taken together, these results suggest that the mechanism that controls expression of flagellar master regulatory genes in response to environmental factors may be largely conserved among Gram-negative bacteria.

Despite the similarities between E. coli and S. typhimurium, some differences have been reported in the regulation of motility in these two organisms. These include the autogenous and global control by H-NS on flhDC master operon expression (Kutsukake, 1997) and the initiation of $f l h D C$ transcription (Soutourina et al., 1999; Yanagihara et al., 1999). On the other hand, some specificities may also exist in the response of these bacteria to acidic $\mathrm{pH}$ (Lin et al., 1995), including the PhoPQ-mediated acid tolerance response (ATR) (Bearson et al., 1998). As the synthesis of H-NS protein has been shown to be unaffected by low $\mathrm{pH}$ (Adams et al., 2001), it has been recently suggested that H-NS is not involved in the control of flagellar biosynthesis in $S$. typhimurium under the acidic conditions tested. Similarly, in E. coli, we observed no alteration in hns expression at acidic $\mathrm{pH}$. However, $f l h D C$ transcription measurement (Fig. 2) and characterization of suppressive mutants (Table 3) demonstrated the role of H-NS protein in motility control under low-pH conditions in E. coli. Nevertheless, these observations do not exclude the possibility that other regulators may participate in this process.

The presence of a $5^{\prime}$ untranslated mRNA region has been usually associated with post-transcriptional regulation mechanisms. For example, such regions are responsible for either transcriptional anti-termination and RNA processing or translational control of threonyl-tRNA synthetase genes in E. coli and Bacillus subtilis (Condon et al., 1997; Putzer et al., 1995; Sacerdot et al., 1998). As compared to the wild-type strain, an up to threefold decrease in $f l h D C$ activity was observed in an hns strain from both transcriptional and translational fusions (Soutourina et al., 1999). More- 
over, a similar reduction in the level of $f l h D C$ mRNA was measured in the hns mutant as compared to the wild-type in RT-PCR experiments and this reduction did not result from an effect of the H-NS protein on the flhDC mRNA stability (Soutourina, 2001). Finally, in vivo activity measurements from a transcriptional fusion containing the extended $f l h D C$ regulatory region (Fig. 2) demonstrated that H-NS, acidic $\mathrm{pH}$ and DNA supercoiling affect the $f h D C$ expression at the level of transcription initiation.

Despite numerous studies on the control of bacterial motility by environmental factors, the molecular basis of this process remains largely unknown. In E. coli, the $\mathrm{H}-\mathrm{NS}$ protein affects the expression of many genes involved in the cellular response to environmental changes, including those required for acidic $\mathrm{pH}$ resistance (Hommais et al., 2001). Although the mechanism by which H-NS controls gene expression remains the subject of debate (Williams \& Rimsky, 1997), an alteration of plasmid and chromosomal DNA supercoiling has been demonstrated in vivo in an hns mutant (Mojica \& Higgins, 1997). Moreover, the involvement of DNA supercoiling has been proposed, for example, to explain the regulation by H-NS of osmotically regulated genes (Higgins et al., 1988), stringently controlled bacterial promoters (Johansson et al., 2000) or virulence gene expression in Shigella flexneri (Dorman et al., 2001). On the other hand, various environmental conditions are also known to affect the level of DNA supercoiling, even though a cause-and-effect relationship has not yet been established (Higgins et al., 1988; Tse-Dinh et al., 1997). It has been proposed that a direct effect of environmental signals on promoter architecture, and then transcription, through influencing the interaction of architectural proteins with DNA, might be an important concept in understanding the environmental regulation of gene expression in bacteria (Jordi et al., 1997). Similarly, different environmental cues might influence the action of H-NS by changing the structure of regulatory regions, the ability of H-NS to bind to DNA target and/or the conformation or the oligomerization state of H-NS. We did not observe any alteration in the level of hns gene expression or in the isoform composition of the H-NS protein under low $\mathrm{pH}$ or in the presence of DNA gyrase inhibitor (data not shown). In contrast, $f h D C$ expression could be modulated by local alteration of DNA topology, resulting from interactions between $\mathrm{H}-\mathrm{NS}$ and the regulatory region. Several observations argue in favour of this hypothesis. First, the alteration of swarming properties in presence of novobiocin, a DNA gyrase inhibitor, or in strains overproducing DNA gyrase or mutated in its structural gene suggests the existence of a critical DNA supercoiling level for normal motility in E. coli (see Results) (Shi et al., 1993b; O.S., unpublished). Second, we observed a severe reduction in $f h D C$ expression when linearized rather than supercoiled plasmid was used in in vitro transcription assay (Fig. 3). Third, the involvement of the extended $f h D C$ regulatory region in the control of the master operon by H-NS, acidic $\mathrm{pH}$ and novobiocin suggests a strong correlation between these regulatory processes (Fig. 2). Finally, further support is provided by the partial restoration of motility in the hns mutant by overexpression of DNA gyrase subunit gene $\operatorname{gyrB}$ (data not shown), and the alteration of topoisomer distribution of plasmids carrying the entire $f l h D C$ regulatory region in the presence of chloroquine phosphate as an intercalating agent (Soutourina, 2001). Taken together, these data suggest that the H-NS-mediated effect on motility may be at least in part explained by an alteration in the level of DNA topology of the $f h D C$ regulatory region. They are consistent with the recent demonstration that a $339 \mathrm{bp}$ DNA fragment having a bent structure can strongly affect the level of plasmid DNA supercoiling (Rohde $e t$ al., 1999) and suggest that the regulatory region of the flagellar master operon may play a crucial role for an adequate control by the H-NS protein and environmental factors.

The control of bacterial motility via the $f l h D C$ operon includes several participants at multiple regulatory levels, e.g. transcription initiation control by cAMPCAP complex and H-NS (Soutourina et al., 1999), mRNA stability control by CsrA (Wei et al., 2001) in E. coli, or FlhDC protein degradation by Lon protease in Proteus mirabilis (Claret \& Hughes, 2000). Our results extend the knowledge of the regulation of the flagellar system and represent an important step toward the understanding of complex mechanisms governing bacterial motility in response to environmental challenges.

\section{ACKNOWLEDGEMENTS}

We are grateful to A. Pugsley for helpful advice and discussions and to G. Karimova for critical reading of the manuscript. We thank A. Kolb for technical assistance in in vitro transcription experiments.

Financial support came from the Institut Pasteur and the Centre National de la Recherche Scientifique (URA 2171). O.S. was supported by a French Government fellowship.

\section{REFERENCES}

Adams, P., Fowler, R., Kinsella, N., Howell, G., Farris, M., Coote, P. \& O'Connor, C. D. (2001). Proteomic detection of PhoPQ- and acid-mediated repression of Salmonella motility. Proteomics 1, 597-607.

Adler, J. (1973). A method for measuring chemotaxis and use of the method to determine optimum conditions for chemotaxis by Escherichia coli. J Gen Microbiol 74, 77-91.

Adler, J. \& Templeton, B. (1967). The effect of environmental conditions on the motility of Escherichia coli. J Gen Microbiol 46, 175-184.

Aizawa, S.-I. \& Kubori, T. (1998). Bacterial flagellation and cell division. Genes Cells 3, 625-634.

Anderson, P. \& Bauer, W. (1978). Supercoiling in closed circular DNA: dependence upon ion type and concentration. Biochemistry 17, 594-601.

Arnold, H. H. \& Winter, B. (1998). Muscle differentiation: more complexity to the network of myodenic regulators. Curr Opin Genet Dev 8, 539-544. 
Bartlett, D. H., Frantz, B. B. \& Matsumura, P. (1988). Flagellar transcriptional activators FlbB and FlaI: gene sequences and 5' consensus sequences of operons under FlbB and FlaI control. $J$ Bacteriol 170, 1575-1581.

Bearson, B., Wilson, L. \& Foster, J. (1998). A low pH-inducible, PhoQP-dependent acid tolerance response protects Salmonella typhimurium against inorganic acid stress. J Bacteriol 180, 2409-2417.

Bertin, P., Lejeune, P., Colson, C. \& Danchin, A. (1992). Mutations in $b g l Y$, the structural gene for the DNA-binding protein $\mathrm{H} 1$ of Escherichia coli, increase the expression of the kanamycin resistance gene carried by plasmid pGR71. Mol Gen Genet 233, 184-192.

Bertin, P., Terao, E., Lee, E. H., Lejeune, P., Colson, C., Danchin, A. \& Collatz, E. (1994). The H-NS protein is involved in the biogenesis of flagella in Escherichia coli. J Bacteriol 176, 5537-5540.

Bertin, P., Benhabiles, N., Krin, E., Laurent-Winter, C., Tendeng, C., Turlin, E., Thomas, A., Danchin, A. \& Brasseur, R. (1999). The structural and functional organization of H-NS-like proteins is evolutionarily conserved in Gram-negative bacteria. Mol Microbiol 31, 319-329.

Bertin, P., Hommais, F., Krin, E., Soutourina, O., Tendeng, C., Derzelle, S. \& Danchin, A. (2001). H-NS and H-NS-like proteins in Gram-negative bacteria and their multiple role in the regulation of bacterial metabolism. Biochimie 83, 235-241.

Bowra, B. J. \& Dilworth, M. J. (1981). Motility and chemotaxis towards sugars in Rhizobium leguminosarum. J Gen Microbiol 126, 231-235.

Bruni, C. B., Colantuoni, V., Sbordone, L., Cortese, R. \& Blasi, F. (1977). Biochemical and regulatory properties of Escherichia coli $\mathrm{K}-12$ his mutants. J Bacteriol 130, 4-10.

Claret, L. \& Hughes, C. (2000). Rapid turnover of FlhD and FlhC, the flagellar regulon transcriptional activator proteins, during Proteus swarming. J Bacteriol 182, 833-836.

Condon, C., Putzer, H., Luo, D. \& Grunberg-Manago, M. (1997). Processing of the Bacillus subtilis thrS leader mRNA is RNase Edependent in Escherichia coli. J Mol Biol 268, 235-242.

Dorman, C. J., McKenna, S. \& Beloin, C. (2001). Regulation of virulence gene expression in Shigella flexneri, a facultative intracellular pathogen. Int J Med Microbiol 291, 89-96.

Farr, S. B., Arnosti, D. N., Chamberlin, M. J. \& Ames, B. (1989). An apaH mutation causes AppppA to accumulate and affects motility and catabolite repression in Escherichia coli. Proc Natl Acad Sci US A 86, 5010-5014.

Goldstein, E. \& Drlica, K. (1984). Regulation of bacterial DNA supercoiling: plasmid linking numbers vary with growth temperature. Proc Natl Acad Sci U S A 81, 4046-4050.

Hengge-Aronis, R. (1999). Interplay of global regulators and cell physiology in the general stress response of Escherichia coli. Curr Opin Microbiol 2, 148-152.

Higgins, C. F., Dorman, C. J., Stirling, D. A., Waddell, L., Booth, I. R., May, G. \& Bremer, E. (1988). A physiological role for DNA supercoiling in the osmotic regulation of gene expression in $S$. typhimurium and E. coli. Cell 52, 569-584.

Hinton, J. C. D., Santos, D. S., Seirafi, A., Hulton, C. J., Pavitt, G. D. \& Higgins, C. F. (1992). Expression and mutational analysis of the nucleoid-associated protein H-NS of Salmonella typhimurium. Mol Microbiol 6, 2327-2337.

Hommais, F., Krin, E., Laurent-Winter, C., Soutourina, O., Malpertuy, A., Le Caer, J. P., Danchin, A. \& Bertin, P. (2001). Large-scale monitoring of pleiotropic regulation of gene ex- pression by the prokaryotic nucleoid-associated protein, H-NS. Mol Microbiol 40, 20-36.

Huang, S. (1999). Gene expression profiling, genetic networks, and cellular states: an integrating concept for tumorigenesis and drug discovery. J Mol Med 77, 469-480.

Johansson, J., Balsalobre, C., Wang, S. Y., Urbonaviciene, J., Jin, D. J., Sonden, B. \& Uhlin, B. E. (2000). Nucleoid proteins stimulate stringently controlled bacterial promoters: a link between the cAMP-CRP and the (p)ppGpp regulons in Escherichia coli. Cell 102, 475-485.

Jordi, B. J. A. M., Fielder, A., Burns, C. M., Hinton, J. C. D., Dover, N., Ussery, D. W. \& Higgins, C. F. (1997). DNA binding is not sufficient for H-NS-mediated repression of proU expression. $J$ Biol Chem 272, 12083-12090.

Kawakami, K., Sato, S., Ozaki, H. \& Ikeda, K. (2000). Six family genes: structure and function as transcription factors and their roles in development. Bioessays 22, 616-626.

Kitamura, E., Nakayama, Y., Matsuzaki, H., Matsumoto, K. \& Shibuya, I. (1994). Acidic-phospholipid deficiency represses the flagellar master operon through a novel regulatory region in Escherichia coli. Biosci Biotechnol Biochem 58, 2305-2307.

Ko, M. \& Park, C. (2000). H-NS-dependent regulation of flagellar synthesis is mediated by a LysR family protein. J Bacteriol 182, 4670-4672.

Kutsukake, K. (1997). Autogenous and global control of the flagellar master operon, flhD, in Salmonella typhimurium. Mol Gen Genet 254, 440-448.

Laurent-Winter, C., Ngo, S., Danchin, A. \& Bertin, P. (1997). Role of Escherichia coli histone-like nucleoid-structuring protein in bacterial metabolism and stress response. Eur J Biochem 244, 767-773.

Lejeune, P. \& Danchin, A. (1990). Mutations in the $b g l Y$ gene increase the frequency of spontaneous deletion in Escherichia coli K-12. Proc Natl Acad Sci U S A 87, 360-363.

Li, C., Louise, C. J., Shi, W. \& Adler, J. (1993). Adverse conditions which cause lack of flagella in Escherichia coli. J Bacteriol 175, 2229-2235.

Lin, J., Lee, I. S., Frey, J., Slonczewski, J. L. \& Foster, J. W. (1995). Comparative analysis of extreme acid survival in Salmonella typhimurium, Shigella flexneri, and Escherichia coli. J Bacteriol 177, 4097-4104.

Macnab, R. M. (1996). Flagella and motility. In Escherichia coli and Salmonella typhimurium: Cellular and Molecular Biology, pp. 123-145. Edited by F. C. Neidhardt and others. Washington, DC: American Society for Microbiology.

Mahan, M. J., Slauch, J. M. \& Mekalanos, J. J. (1996). Environmental regulation of virulence gene expression in Escherichia, Salmonella, and Shigella spp. In Escherichia coli and Salmonella typhimurium: Cellular and Molecular Biology, pp. 2803-2815. Edited by F. C. Neidhardt and others. Washington, DC: American Society for Microbiology.

Miller, J. H. (1992). A Short Course in Bacterial Genetics. Cold Spring Harbor, NY: Cold Spring Harbor Laboratory.

Mizushima, T., Koyanagi, R., Suzuki, E., Tomura, A., Kutsukake, K., Miki, T. \& Sekimizu, K. (1995). Control by phosphatidylglycerol of expression of the $f l h D$ gene in Escherichia coli. Biochim Biophys Acta 1245, 397-401.

Mizushima, T., Koyanagi, R., Katayama, T., Miki, T. \& Sekimizu, K. (1997). Decrease in expression of the master operon of flagellin synthesis in a dnaA46 mutant of Escherichia coli. Biol Pharm Bull 20, 327-331. 
Mojica, F. J. M. \& Higgins, C. F. (1997). In vivo supercoiling of plasmid and chromosomal DNA in an Escherichia coli hns mutant. J Bacteriol 179, 3528-3533.

Putzer, H., Grunberg-Manago, M. \& Springer, M. (1995). Bacterial aminoacyl-tRNA synthetases: genes and regulation of expression. In tRNA: Structure, Biosynthesis and Function, pp. 293-333. Edited by D. Soll \& U. L. RajBhandary. Washington, DC: American Society for Microbiology.

Relaix, F. \& Buckingham, M. (1999). From insect eye to vertebrate muscle: redeployment of a regulatory network. Genes Dev 13, 3171-3178.

Rohde, J. R., Fox, J. M. \& Minnich, S. A. (1994). Thermoregulation in Yersinia enterocolitica is coincident with changes in DNA supercoiling. Mol Microbiol 12, 187-199.

Rohde, J. R., Luan, X. S., Rohde, H., Fox, J. M. \& Minnich, S. A. (1999). The Yersinia enterocolitica pYV virulence plasmid contains multiple intrinsic DNA bends which melt at $37^{\circ} \mathrm{C} . \mathrm{J}$ Bacteriol 181, 4198-4204.

Romeo, T. (1998). Global regulation by the small RNA-binding protein CsrA and the non-coding RNA molecule CsrB. Mol Microbiol 29, 1321-1330.

Sacerdot, C., Caillet, J., Graffe, M., Eyermann, F., Ehresmann, B., Ehresmann, C., Springer, M. \& Romby, P. (1998). The Escherichia coli threonyl-tRNA synthetase gene contains a split ribosomal binding site interrupted by a hairpin structure that is essential for autoregulation. Mol Microbiol 29, 1077-1090.

Shi, W., Zhou, Y., Wild, J., Adler, J. \& Gross, C. A. (1992). DnaK, DnaJ, and GrpE are required for flagellum synthesis in Escherichia coli. J Bacteriol 174, 6256-6263.

Shi, W., Bogdanov, M., Dowhan, W. \& Zusman, D. R. (1993a). The pss and psd genes are required for motility and chemotaxis in Escherichia coli. J Bacteriol 175, 7711-7714.

Shi, W., Li, C., Louise, C. \& Adler, J. (1993b). Mechanism of adverse conditions causing lack of flagella in Escherichia coli. J Bacteriol 175, 2236-2240.

Silverman, M. \& Simon, M. (1974). Characterization of Escherichia coli flagellar mutants that are insensitive to catabolite repression. J Bacteriol 120, 1196-1203.
Soutourina, O. (2001). Control of gene expression in the motility process in Gram-negative bacteria. PhD thesis, University of Versailles-Saint-Quentin.

Soutourina, O., Kolb, A., Krin, E., Laurent-Winter, C., Rimsky, S., Danchin, A. \& Bertin, P. (1999). Multiple control of flagellum biosynthesis in Escherichia coli: role of $\mathrm{H}-\mathrm{NS}$ protein and the cyclic AMP-catabolite activator protein complex in transcription of the flhDC master operon. J Bacteriol 181, 7500-7508.

Soutourina, O. A., Semenova, E. A., Parfenova, V. V., Danchin, A. \& Bertin, P. (2001). Control of bacterial motility by environmental factors in polarly flagellated and peritrichous bacteria isolated from Lake Baikal. Appl Environ Microbiol 67, 3852-3859.

Stocker, B. A. D. \& Campbell, J. C. (1959). The effect of non-lethal deflagellation on bacterial motility and observations on flagellar regeneration. J Gen Microbiol 20, 670-685.

Tse-Dinh, Y. C., Qi, H. \& Menzel, R. (1997). DNA supercoiling and bacterial adaptation: thermotolerance and thermoresistance. Trends Microbiol 5, 323-326.

Wei, B. L., Brun-Zinkernagel, A.-M., Simecka, J. W., Pruss, B. M., Babitzke, P. \& Romeo, T. (2001). Positive regulation of motility and $f l b D C$ expression by the RNA-binding protein CsrA of Escherichia coli. Mol Microbiol 40, 245-256.

Weibull, C. (1948). Some chemical and physico-chemical properties of the flagella of Proteus vulgaris. Biochim Biophys Acta 2, 351-355.

Williams, R. M. \& Rimsky, S. (1997). Molecular aspects of the Escherichia coli nucleoid protein, H-NS: a central controller of gene regulatory networks. FEMS Microbiol Lett 156, 175-185.

Yanagihara, S., lyoda, S., Ohnishi, K., lino, T. \& Kutsukake, K. (1999). Structure and transcriptional control of the flagellar master operon of Salmonella typhimurium. Genes Genet Syst 74, $105-111$.

Yokota, T. \& Gots, J. (1970). Requirement of adenosine 3', 5'-cyclic monophosphate for flagellation in Escherichia coli and Salmonella typhimurium. J Bacteriol 103, 513-516.

Received 1 November 2001; revised 9 January 2002; accepted 17 January 2002. 